\title{
Chemical properties and evolution of mid-ocean ridge hydrothermal systems-flow system approach-
}

\author{
HODAKA KaWAHATA \\ Geological Survey of Japan, 1-1-3 Higashi, Tsukuba Ibaraki, 305, Japan
}

(Received September 13, 1989; Accepted January 11, 1990)

\begin{abstract}
Low water/rock ratios (about 1 in weight) in discharge zone appear to be an important characteristic of submarine hydrothermal systems associated with axial spreading centers. These ratios, which are stable over time, are linked with the chemistry of end-member hydrothermal solutions (original hydrothermal solution before mixing with ambient seawater) and the chemistry and distribution of greenstones. These features are considered to result from the properties of an open flow system.

This paper is an attempt to analyze a submarine hydrothermal system, using an ideal open flow model. In this model, seawater is percolating through a rock column which is divided into a number of cells. In each cell, both rocks and solutions come to equilibrium, based on strontium isotope exchange.

The fundamental features of water/rock interaction in this flow system differ from those inferred from closed system; (1) chemical composition of the discharged solution can be kept constant for some while although large volume of recharged solution brings large change in the bulk chemical composition of the system. (2) The difference between chemical composition of recharged and discharged solutions is compensated by the large change of rock composition near recharge zone at earlier stage of hydrothermal system. (3) The values of water/rock ratio deduced from rock or solution chemistry are, in general, different from the integrated volume water/rock ratio.

These results are applied to the natural subseafloor hydrothermal system. The features are classified in relation to three evolutionary stages: (1) Early stage: chlorite-quartz-(CQ-) and CQ-rich greenstones occur only in recharge zone while CQ-poor greenstones occur in the rest of the system. (2) Intermediate stage: the increase of fluid flow promotes replacement of CQ-poor with CQ-rich and some of CQ-rich with CQ-greenstones, respectively. (3) Late stage: CQ-poor greenstones are completely replaced by CQand CQ-rich greenstones.

The integrated volume water/rock ratio ([W/R $]_{\text {FLow }}$ ) constrained by the energy of heat source is estimated to be up to 4 . So it is suggested that hydrothermal activity dies out by the intermediate stage. The chemical composition of end-member hydrothermal solutions stays constant through the early and intermediate stage. An increase of integrated water volume circulating through the system does not necessarily lead to change the chemistry of hydrothermal solution and host rock through the system.
\end{abstract}

\section{INTRODUCTION}

In the last decade, several axial hydrothermal systems along mid-ocean ridges have been discovered (e.g. Edmond et al., 1979; Rise Project Group, 1980; Hekinian et al., 1980; East Pacific Rise Study Group, 1981; Michard et al., 1981; McConachv et al., 1986). An important and interesting characteristic of these systems is the narrow range of water/rock ratios (1 to 5 in weight) estimated from end-member hydrother- mal solutions (Corliss et al., 1979; Albarede et al., 1981; Edmond et al., 1982, 1985; Von Damm et al., 1985). Edmond et al. (1985) have shown that the chemical composition of endmember hydrothermal solutions from $21^{\circ} \mathrm{N}$, EPR has remained constant over the six years since they were first measured in 1979. Furthermore, the sulfur isotope values of sulfide deposits from $21^{\circ} \mathrm{N}$, EPR, Juan de Fuca, Explorer Ridge, and Axial Seamount lie in a narrow range $\left(\delta^{34} \mathrm{~S}=0\right.$ to $5 \%$ ) (Shanks et al., 1984; 
Table 1. Characteristics on rock chemistry, solution chemistry, and secondary minerals versus water/rock ratio $\left([\mathrm{W} / \mathrm{R}]_{\text {CHEM }}\right)$

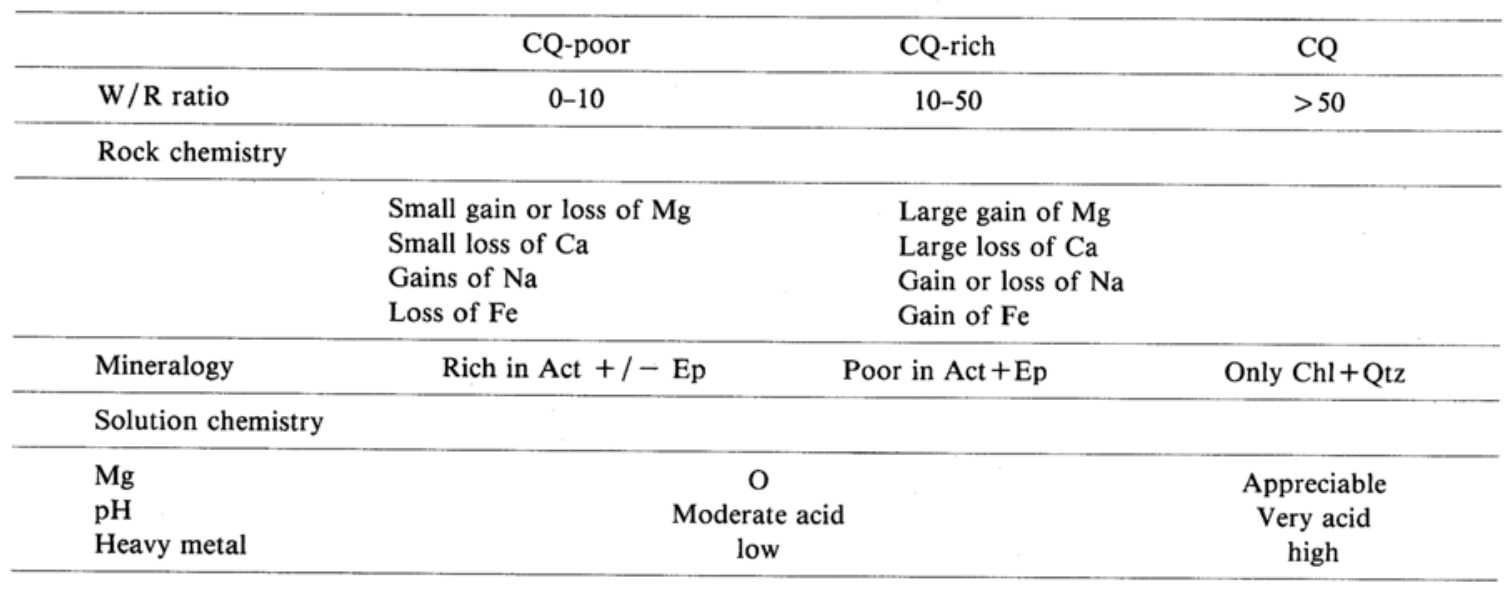

(CQ: chlorite-quartz) (Act: Actinolite, Ep: Epidote, Chl: Chlorite, Qtz: Quartz) (from Mottl, 1983).

Zierenberg et al., 1984) and indicate that the sulfides precipitated from hydrothermal solutions at low water/rock ratios (about 1 to 5), based on the models by Shanks et al. (1984) and Zierenberg et al. (1981). In addition to present seafloor hydrothermal fields, strontium isotopic data from DSDP Hole 504B, drilled into a $500 \mathrm{~m}$ thick greenstone sequence in the Costa Rica Rift, indicate that the greenstones in a discharge zone were formed under a low water/rock ratio of 1.6 (Kawahata et al., 1987). These lines of evidence suggest that low water/rock ratios of endmember hydrothermal solutions and greenstones in discharge zones were stable with time during the period of hydrothermal activity associated with axial spreading centers.

For the axial system at $21^{\circ} \mathrm{N}, \mathrm{EPR}$, neither an ordinary closed system nor an open system can explain the production of narrow range of the chemical and isotopic compositions of hydrothermal solutions and their constancy with time (Edmond et al., 1985). Seawater percolating in oceanic crust reacts with surrounding rocks, changing the chemical composition of both rocks and water. Since the chemical composition of recharged seawater is different from that of discharged hydrothermal solution (Edmond et al., 1985), an increase in the volume of water circulating through the system should change the bulk chemical composition of the hydrothermal system. This change is expected to affect the chemistry and mineral assemblages of altered rocks and hot spring chemistry.

A number of closed-system basalt-seawater experiments at high temperatures $\left(150-500^{\circ} \mathrm{C}\right)$ show that the chemistries of altered rocks and modified solutions are controlled mainly by the parameter water/rock ratio (in weight, $[\mathrm{W} / \mathrm{R}]_{\mathrm{CHEM}}$ ) as well as by temperature (Bischoff and Dickson, 1975; Hajash, 1975; Mottl and Holland, 1978; Seyfried and Mottl, 1982; Bowers and Taylor, 1985). These works were so successful that Mottl (1983) was able to infer the relationship between the chemistries of several kinds of metabasalts and hydrothermal solutions (Table 1). The present study extends the work of Mottl (1983) by combining data deduced from a closed system with fundamental chemical properties expected from an open flow system to quantify his model.

Fortunately, initial oceanic crust and seawater, before hydrothermal alteration, have fairly uniform isotopic ratios and chemical compositions. The birth of a hot spring solution and the evolution of a hydrothermal system may be simulated by simplifying the natural system to an ideal flow model. In this model, seawater percolates through a rock column which is divided 
into a number of cells. In each cell, both rocks and solutions come to chemical and isotopic equilibrium. Here the strontium isotopic values, which are linked with water/rock ratio, are traced with time through the system.

The objectives of this paper are (1) to clarify the difference between flow and closed systems, (2) to indicate the difference between a water/rock ratio deduced from the rock or solution chemistries ([W/R $]_{\text {CHEM }}$ ) and an integrated water/rock ratio ([W/R $]_{\text {FLOW }}$ ) (3) to emphasize a capacity and process to keep the chemical and isotopic compositions of discharged hydrothermal solutions constant, (4) to discuss its application to the natural subseafloor hydrothermal system.

\section{Ideal Flow Model and Simulation OF Mid-OcEan Ridge Hydrothermal SySTEM}

Physical constraints of hydrothermal circulation system

Seawater enters the convection system in a recharge zone within a few kilometers from the spreading axis (Spooner and Fyfe, 1973; Wolery and Sleep, 1976). This downwelling seawater in an axial hydrothermal system traverses an extremely steep temperature gradient within the upper oceanic crust, from about 0 to $250-450^{\circ} \mathrm{C}$, causing seawater sulfate to precipitate as anhydrite (Mottl, 1983). At such high temperatures, it is suggested that solutions react with rocks in relatively short time (Bischoff and Dickson, 1975, Seyfried and Bischoff, 1977, 1981; Seyfried and Mottl, 1982). The main flow path is assumed to go down to about 1 to $2.5 \mathrm{~km}$ subbottom depth, to the uppermost gabbroic layer, based on little strontium contamination of gabbroic sequence (Spooner et al., 1977a, b) and on temperature and chemistry of hot spring solution (Bischoff, 1980; Hekinian et al., 1980; Von Damm et al., 1985). If the solution cools adiabatically as it rises (Bischoff, 1980), the tem-

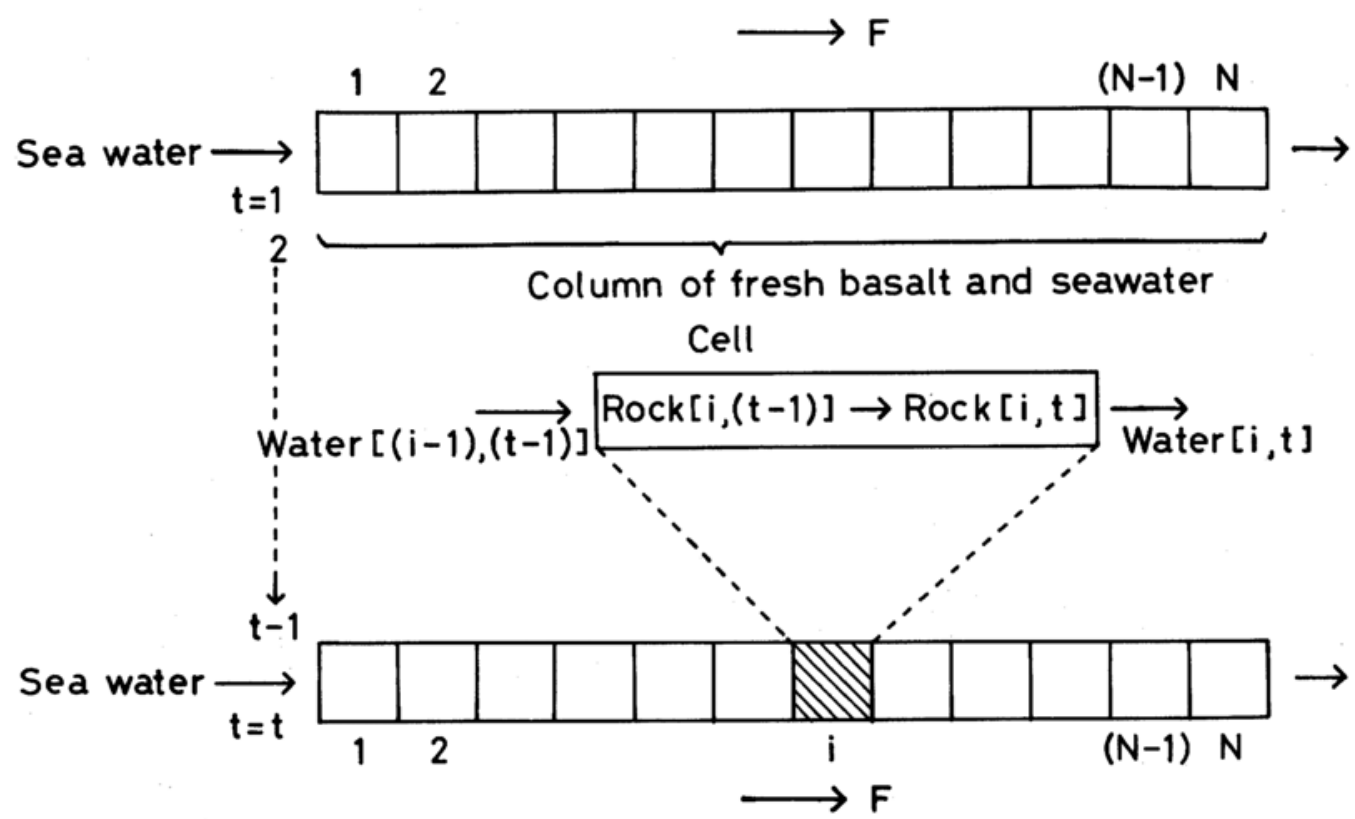

Fig. 1. Model for numerically computing incremental equilibrium element and/or isotope exchange in an isothermal flow system. An initially fresh column of basalt and seawater is split into cells (1 . N). Solution flow is modeled by the passage of successive increments $(1 \ldots t)$ of seawater (initially fresh composition) through the column. The reaction between rock and solution in each cell attains chemical and isotopic equilibria, then the solution proceeds to the next cell. 
perature and pressure at the base of the upflow zone is probably in the range 350 to $370^{\circ} \mathrm{C}$ and 500 to 700 bars for a typical axial hydrothermal system. These ranges are similar to conditions of greenstone formation (East Pacific Rise Study Group, 1981; Mottl, 1983). Hot spring solution mixes with cold seawater on, or within the crust and forms sulfide/oxide deposits.

\section{Ideal flow model}

In this study chemical properties of flow paths are analyzed by adopting an ideal flow model where incremental equilibrium is attained during the reaction between rock and solution in a differential portion of the system (Fig. 1). The differential portion is called a cell here. Seawater is percolating through a rock column which is divided into $\mathrm{N}$ cells. Each cell has a length $\mathrm{L}$. The reaction between solution and rock attains chemical and isotopic equilibrium in each cell. Following equilibrium in each cell, the reacted solution proceeds to the next cell, where it reacts with the rocks and reequilibrates. The continuous inflow of recharged seawater and outflow of discharged solution make solution advance in the direction $F$. This sequence takes place in all cells (Fig. 1).

The model is justified based upon the following considerations: (1) basalt-seawater experiments indicate that the reaction between basalt and seawater attains steady state or almost equilibrium in a short time (within one year) above $300^{\circ} \mathrm{C}$ (Seyfried, 1977; Seyfried and Bischoff, 1977, 1981; Mottl and Seyfried, 1980; Seyfried and Mottl, 1982). Their results, in spite of closed systems, are consistent with chemical properties of end-member hydrothermal solutions formed in natural flow systems (Mottl, 1983; Von Damm et al., 1985). (2) DSDP Hole $504 \mathrm{~B}$ is the only hole that contains hydrothermally altered rocks of greenschist facies in all the DSDP Holes drilled in typical oceanic crust (Anderson et al., 1982). The bulk permeability of the greenschist-altered sheeted dike zone from DSDP Hole 504B is very low (less than $10^{-18} \mathrm{~m}^{2}$ (10 mdarcy)) (Becker et al., 1983), which implies very slow flow velocities for circulating solu- tions. Thus solutions should achieve local equilibrium while circulating at elevated temperature. (3) The distribution and chemistry of altered rocks from the recharge zone in the Troodos and Liguria ophiolite suites in Cyprus can be explained using a similar ideal flow model (Spooner et al., 1977a, b).

The reaction between rock and seawater at low temperature $\left(<50^{\circ} \mathrm{C}\right)$ is so slow that a detectable change in chemical composition of weathered rocks requires time on the order of a million years (Hart, 1970; 1973). Thus it is suggested that seawater arrives with little or no change in its chemical composition at a place where an extremely steep temperature gradient exists. The ideal flow model of this study begins at this point. The hydrothermal solution rises up rapidly and adiabatically. The discharge zone of this study corresponds to the bottom of an upflow zone.

\section{Definition of water/rock ratio}

For a natural hydrothermal system taken as a whole, the integrated water/rock ratios may be defined as the total mass of water that has passed through the system, integrated through time, divided by the total mass of altered rocks within the $\operatorname{system}\left([\mathrm{W} / \mathrm{R}]_{\mathrm{FLOW}}\right.$ ) (formula (1) (Mottl, 1983)):

$$
[\mathrm{W} / \mathrm{R}]_{\mathrm{FLOW}}=\mathrm{W} / \mathrm{R},
$$

where $\mathrm{W}$ is the weight of convected solution which has passed through the system and $R$ is the weight of the altered rocks in the total system that have been affected by this solution. In the model calculation in this paper, $[\mathrm{W} / \mathrm{R}]_{\mathrm{FLOW}}$ represents the ratio of the total mass of water having passed through the column to the total mass of altered rocks through time.

The water/rock ratio ([W/R $]_{\text {CHEM }}$ ) for the closed system experiments (Bischoff and Dickson, 1975; Hajash, 1975; Seyfried, 1977; Seyfried and Bischoff, 1977, 1981; Mottl and Holland, 1978; Mottl and Seyfried, 1980; Seyfried and Mottl, 1982) is simply the ratio of the mass of water to that of rock initially contained in the experimental charge. 
The water/rock ratio (in weight) in relation to strontium isotopic ratios is given by the following equation taken from Albarede et al. (1981):

$$
\begin{aligned}
& {[\mathrm{W} / \mathrm{R}]_{\text {CHEM }}} \\
& =\frac{\left(\left[{ }^{87} \mathrm{Sr} /{ }^{86} \mathrm{Sr}\right]_{\mathrm{F}}^{\text {ROCK }}-\left[{ }^{87} \mathrm{Sr} /{ }^{86} \mathrm{Sr}\right]^{\text {ROCK }}\right) \times \mathrm{C}^{\text {ROCK }}}{\left(\left[{ }^{87} \mathrm{Sr} /{ }^{86} \mathrm{Sr}\right]_{1}^{\text {WATER }}-\left[{ }^{87} \mathrm{Sr} /{ }^{86} \mathrm{Sr}\right]_{\mathrm{F}}^{\text {WATER }}\right) \times \mathrm{C}^{\text {WATER }}},
\end{aligned}
$$

where

I = the initial values of fresh basalt and seawater,

$\mathrm{F}=$ the final values after basalt-seawater interaction,

and

$$
\begin{aligned}
& \mathrm{C}=\text { the strontium concentration in water or } \\
& \text { rock. }
\end{aligned}
$$

Strontium isotope exchange between rocks and solution in each cell and rock column

The evolution of the rock column can be traced by calculating the water/rock ratios, using eq. (2), from the compositions of rocks and seawater in each cell at a given time. In other words, a pseudoflow is used to make good use of experiments and thermodynamic calculations done in closed systems. Here, the distribution of strontium isotopic ratios is investigated because their fractionation is almost independent of coexisting minerals, temperature, and pressure. Further, it has a relation to a water/rock ratio ([W/R $]_{\text {CHEM }}$ ) by a mass balance calculation.

The strontium concentration of end-member hydrothermal solutions is almost the same as that of seawater (Corliss et al., 1979; Albarede et al., 1981; Von Damm et al., 1985), which means that neither addition nor loss of strontium is found during hydrothermal alteration near discharge zone (Spooner et al., 1977b). It corresponds to the exchange of strontium isotope between rock and water for a cell.

When water of the flow system shown in Fig. 1 enters the next cell after equilibrium with rocks, the values of parameter $t$ increases by one. The duration time of each cell will be dis- cussed later. The isotope ratio of the rock of i'th cell after equilibrium exchange with the water of $t$ passage is given by:

$$
\begin{aligned}
R(i, t)= & \left(C_{\text {WATER }} / C_{\text {ROCK }}\right) \times(W(i-1, t-1) \\
& -W(i, t)) / r+R(i, t-1),
\end{aligned}
$$

where

$\mathrm{R}(\mathrm{i}, \mathrm{t})$ is the final ${ }^{87} \mathrm{Sr} /{ }^{86} \mathrm{Sr}$ ratio of the rock in equilibrium with the water in i'th cell at time $t$, $\mathrm{W}(\mathrm{i}, \mathrm{t})$ is the final ${ }^{87} \mathrm{Sr} /{ }^{86} \mathrm{Sr}$ ratio of the water in equilibrium with the water in $i$ 'th cell at time $t$, which is equal to $R(i, t)$

and

$r$ is the water/rock ratio in weight.

In the formula (3), $\mathrm{C}_{\text {WATER }}, \mathrm{C}_{\mathrm{ROCK}}$, and $\mathrm{r}$ are constant and $\mathrm{W}(\mathrm{i}-1, \mathrm{t}-1)$ and $\mathrm{R}(\mathrm{i}, \mathrm{t}-1)$ are known, so $R(i, t)$ can be calculated.

\section{Initial condition of flow system}

Spooner et al. (1977a) adopted a similar model to discuss the contamination of altered rocks in an ophiolite by seawater components, assuming that no water was in the system prior to the hydrothermal activity. However, this initial condition is not realistic because permeability of the upper oceanic crust (volcanics and sheeted dike zones) is high enough for seawater to penetrate. In addition, their calculation produced a hydrothermal solution with an extremely low water/rock ratio of about zero. Thus, in my model, space among pillow lavas and sheeted dikes is filled with fresh seawater at the beginning of the hydrothermal activity.

Initial ${ }^{87} \mathrm{Sr} /{ }^{86} \mathrm{Sr}$ ratios of fresh basalt and seawater are 0.70265 (Hart et al., 1974) and 0.7090 (Veizer and Compton, 1974; Burk et al. 1982), respectively. Strontium, calcium, and sulfate concentrations are 8,400 , and $2760 \mathrm{ppm}$ in seawater and 8,1000 , and $0 \mathrm{ppm}$ in a hydrothermal solution, respectively (Albarede $e t$ al., 1981; Von Damm et al., 1985). Strontium and calcium oxide $(\mathrm{CaO})$ contents of rocks are $93 \mathrm{ppm}$ and $11.88 \mathrm{wt} . \%$ (Hart et al., 1974), respectively. These values are representative of 


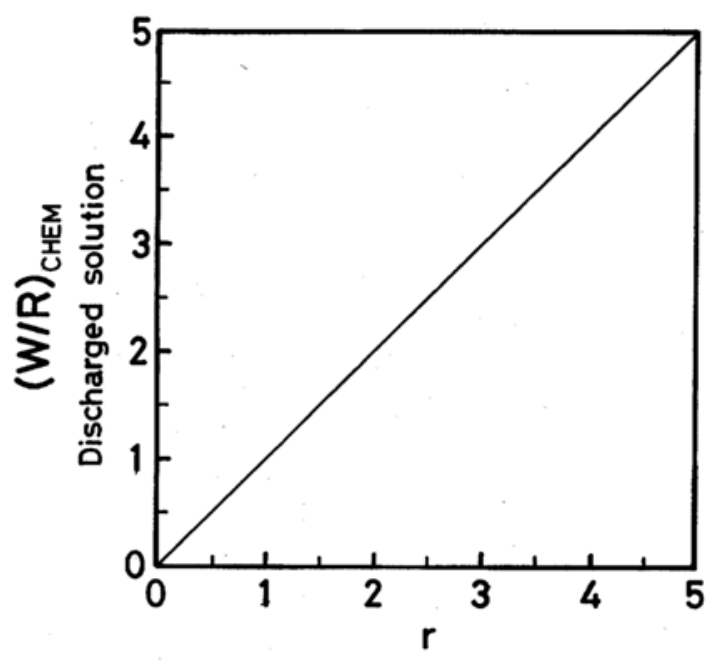

Fig. 2. The relation between parameter $(r)$ and $[W / R]_{\text {CHEM }}$ of discharged solution during early and intermediate evolutionary stages. The parameter $r$ represents the weight ratio of seawater to rock in each cell. If equilibrium is attained in each cell, chemical and isotopic compositions of discharged solution are linked with $[W / R]_{\text {CHEM }}$.

natural submarine hydrothermal system. There are many arguments on anhydrite formation in recharge zones of hydrothermal systems (e.g. Bischoff and Dickson, 1975; McDuff and Edmond, 1982; Mottl, 1983). Thus, calculations were done assuming both anhydrite formation and no anhydrite formation. It appears that precipitation of anhydrite has a negligible effect in the following interpretation, because the difference in strontium isotopic ratios between the two cases is less than 0.00004 . When anhydrite is formed, calcium must be supplied from rocks as well as from seawater to precipitate all seawater sulfate $(28.8 \mathrm{mM})$. At that time strontium is also leached from the rocks at a weight ratio of 0.0011 to calcium which is the same order of magnitude as that of a fresh rock (Humphris and Thompson, 1978). The strontium concentration of anhydrite is calculated based upon the partitioning experiments (Shikazono and Holland, 1983).

Water reacts with rock in the cell with the weight ratio (r). The chemistry of end-member solution is calculated as a function of the parameter (r) in Fig. 2. The weight ratio (r) is assumed to be 1.0 because end-member hydrothermal solutions from submarine hydrothermal fields $\left(21^{\circ} \mathrm{N}, \mathrm{EPR}, 87^{\circ} \mathrm{W}\right.$, Galapagos Spreading Center, DSDP Hole 504B) were formed under a similar water/rock ratio of about unity. The temperature through the rock column is assumed to be $350^{\circ} \mathrm{C}$. The steep temperature gradient in the downflow zone (Mottl, 1983) suggests that minor errors may be involved in the calculations with this asumption.

The most poorly known parameter is $\mathrm{N}$, the total number of cells. Since it is assumed that the solution moves into the next cell after local equilibrium, the parameter $\mathrm{N}$ depends mainly upon flow velocity and reaction kinetics. Most workers considering flow velocities have used a crack model (e.g. Lister, 1974; Lowell, 1975). Lowell (1975) points out that flow velocity varies as the cube of the crack thickness, so any disccussion of such velocities must depend on estimation of crack width and frequency. Circulation time is estimated to range from 4 (Ribando et al., 1976) to $10^{4}$ years (Lowell, 1975)(with large uncertainty). Ribando et al. (1976) considers flow velocities of the order of $5 \times 10^{-3} \mathrm{~cm} / \mathrm{s}$ and circulation time of 4 years, not unreasonable for a crack width of $0.05 \mathrm{~mm}$. If the velocity $\left(1 \times 10^{-4} \mathrm{~cm} / \mathrm{s}\right)$ of the cracking front penetrating through hot rock is similar to flow velocity, the circulation time is estimated to be 200 years (Lister, 1974). The flow rate of hot spring solutions at $21^{\circ} \mathrm{N}, \mathrm{EPR}$ is $214 \mathrm{~cm} / \mathrm{s}$ with an area of $10^{3} \mathrm{~cm}^{3}$ (Converse et al., 1984). If it is assumed that (1) seawater enters the hydrothermal system in an area of $1 \mathrm{~km}^{2}$ around the hydrothermal mounds, that (2) hydrothermal solutions pour out at the same velocity and in the area as $21^{\circ} \mathrm{N}$, EPR, and that (3) the porosity of upper oceanic crust is $15 \%$ to $20 \%$ (Rise Project Group, 1980 and references therein), then the flow rate is estimated as $4 \times 10^{-4} \mathrm{~cm} / \mathrm{s}$ with one circulation time of about 50 years. These estimations suggest that it takes a few to a few hundred years for one circulation.

When flow velocities and a length of one cell are taken as $\mathrm{v}$ and $\mathrm{L}$, it takes $\mathrm{L} / \mathrm{v}$ (years) to pass 
through one cell, and $\mathrm{N} \times \mathrm{L} / \mathrm{v}$ (years) through the rock column, respectively. For example, using a 50-year period for one circulation and one year for local equilibrium of basalt-seawater interaction at $350^{\circ} \mathrm{C}$, the total number of cells is 50.

\section{Results AND Discussion}

\section{Characteristics of flow system}

Simulation of the above model is shown in Figs. 3 and 4. The fundamental features of the profiles can be described in a context of three evolutionary stages which are summarized in Table 2. The profiles of strontium isotopic ratios and water/rock ratios ([W/R $]_{\text {CHEM }}$ ) are shown with a parameter of the total number of cells $\mathrm{N}$ (Fig. 3). Fortunately the two conditions $(\mathrm{N}=50$, 100) affect the profiles so little that only minor errors are introduced in the following interpretation Large chemical effect of seawater components added to crystalline rocks is (1) limited to a recharge zone in the early evolutionary stage (Fig. 3a); (2) reaches up to the central zone in the intermediate evolutionary stage (Fig. 3b); and (3) covers almost all the system in the late evolutionary stage (Fig. 3c).

Figure 4 compares the chemical changes of the discharge solution deduced from the present flow model with that of a closed system model as a function of time. In the closed system, the chemical composition of the solution should change as the integrated volume water/rock ratio ([W/R $]_{\text {FLOW }}$ ) changes, since complete mixing and equilibrium can be attained. In the open system, on the other hand, the chemical composition of the solution can be kept constant for a while in spite of large changes in the bulk chemical composition of the system.

The mechanism to keep the chemical composition of discharged solution constant for much of the life time of the hydrothermal system is a very important process of the flow system. This property also results in the presence of chlorite quartz (CQ-)poor greenstones which escape metasomatic processes in the discharge zone. A continuous influx of seawater will not affect rock chemistry in the discharge zone because seawater loses its ability to change the rock chemistry, having already passed through and reacted with surrounding rocks. The difference between the chemical compositions of recharge and discharge solutions is compensated not by the homogeneous changes of the whole system but by the large change of the rock composition only near the recharge zone until an integrated volume water/rock ratio ([W/R $]_{\text {FLOw }}$ ) becomes around 4.0 (early and intermediate evolution stages).

The chemical compositions of both rocks and solutions change systematically in the flow system. The ([W/R $]_{\text {CHEM }}$ ) values as a function of time are compared with three parts of rock column in Fig. 4. These results indicate that the values of water/rock ratio deduced from chemistry $\left([\mathrm{W} / \mathrm{R}]_{\mathrm{CHEM}}\right)$ are, in general, different

Table 2. Characteristics of flow system versus different evolution stages and portions in flow column

\begin{tabular}{|c|c|c|c|}
\hline Evolution stage & Early & Intermediate & Late \\
\hline$[\mathrm{W} / \mathrm{R}]_{\mathrm{FLOW}}^{\mathrm{SYS}}$ & 1.0 & 4.0 & 10.0 \\
\hline \multicolumn{4}{|c|}{$[\mathrm{W} / \mathrm{R}]_{\mathrm{CHEM}}$ and rock types of greenstone } \\
\hline Recharge zone & $\begin{array}{c}\text { High } \\
\text { CQ-rich }\end{array}$ & $\begin{array}{l}\text { Very high } \\
\text { CQ- }\end{array}$ & $\begin{array}{l}\text { Very high } \\
\text { CQ- }\end{array}$ \\
\hline Center zone & $\begin{array}{l}\text { Low (1.0) } \\
\text { CQ-poor }\end{array}$ & $\begin{array}{l}\text { From low to high } \\
\text { CQ-poor and -rich }\end{array}$ & $\begin{array}{l}\text { Very high } \\
\text { CQ- }\end{array}$ \\
\hline Discharge zone & $\begin{array}{l}\text { Low }(1.0) \\
\text { CQ-poor }\end{array}$ & $\begin{array}{l}\text { Low (1.0) } \\
\text { CQ-poor }\end{array}$ & $\begin{array}{l}\text { From low to high } \\
\text { CQ-poor and CQ-rich }\end{array}$ \\
\hline
\end{tabular}



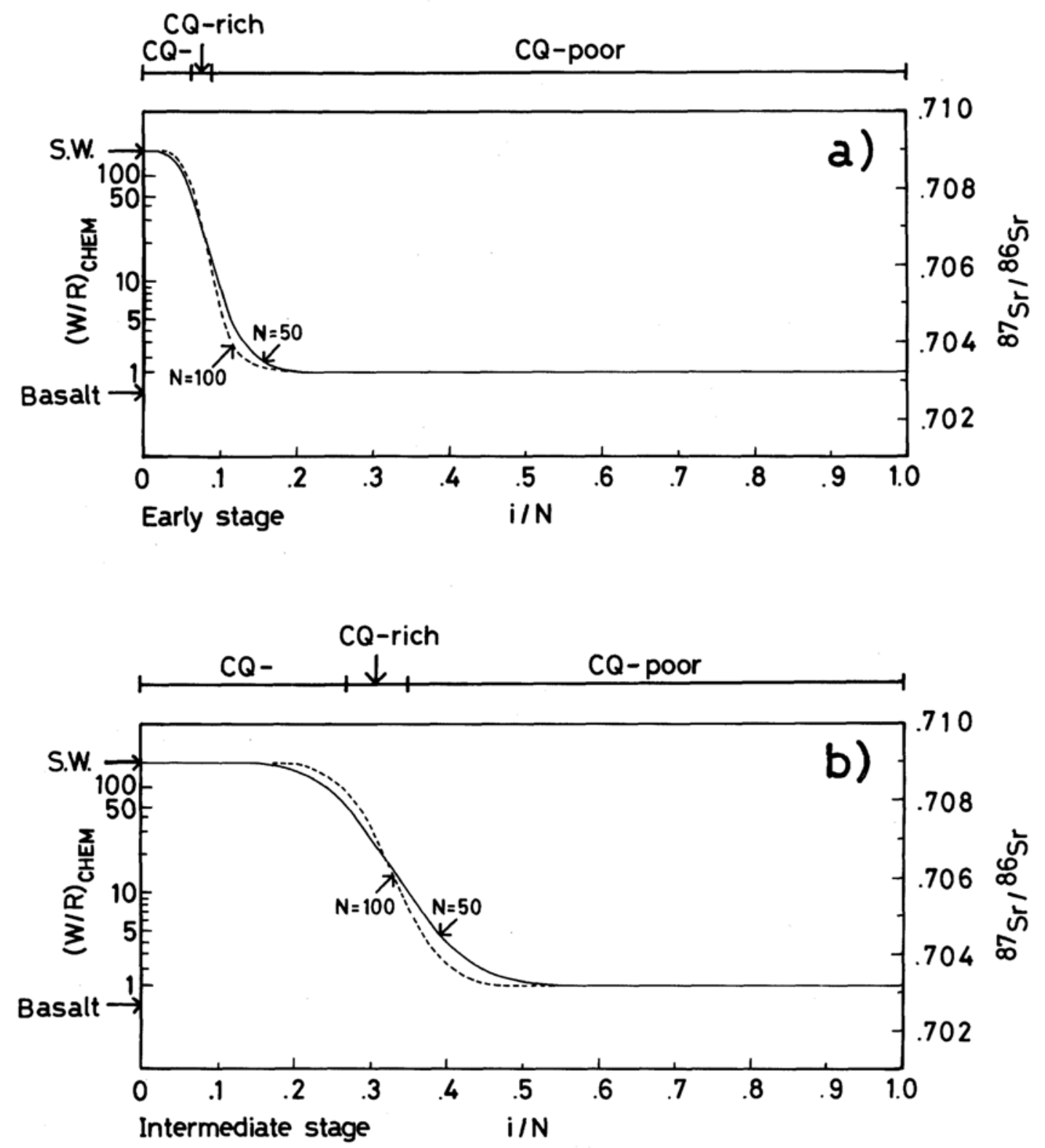

Fig. 3. Strontium isotope exchange in the ideal flow model. Distribution of strontium isotopic ratios of altered rocks in rock column at different integrated volume water/rocks in rock column at different integrated volume water/rock ratios $\left([W / R]_{F L O W}^{S Y S}\right)$. Solid and broken lines indicate the profiles for the total cell number $(N)$ to and 100 , respectively. a) Early evolution stage $\left([W / R]_{F L O W}^{S Y S}=1\right)$, b) intermediate stage $\left([W / R]_{F L O W}^{S Y S}=4\right)$, and c) late stage $\left([W / R]_{F L O W}^{S Y S}=10\right)$.

from the integrated volume water/rock ratio $\left([\mathrm{W} / \mathrm{R}]_{\mathrm{FLOW}}\right)$. For example, in the intermediate evolutionary stage $\left([\mathrm{W} / \mathrm{R}]_{\mathrm{FLOW}}=4\right.$, line a in Fig. $4),[\mathrm{W} / \mathrm{R}]_{\text {CHEM }}$ is very high $(>50)$ in the recharge zone, whereas it is low (1.0) in the discharge zone
(Fig. 3B). There is only one point (A) where $[\mathrm{W} / \mathrm{R}]_{\mathrm{CHEM}}$ and $\left.[\mathrm{W} / \mathrm{R}]_{\mathrm{FLOW}}\right)$ are equal. In general, the strontium isotopic value and [W/R] СнEм are lower in the discharge zone than in the recharge zone, and rock and solution have a 

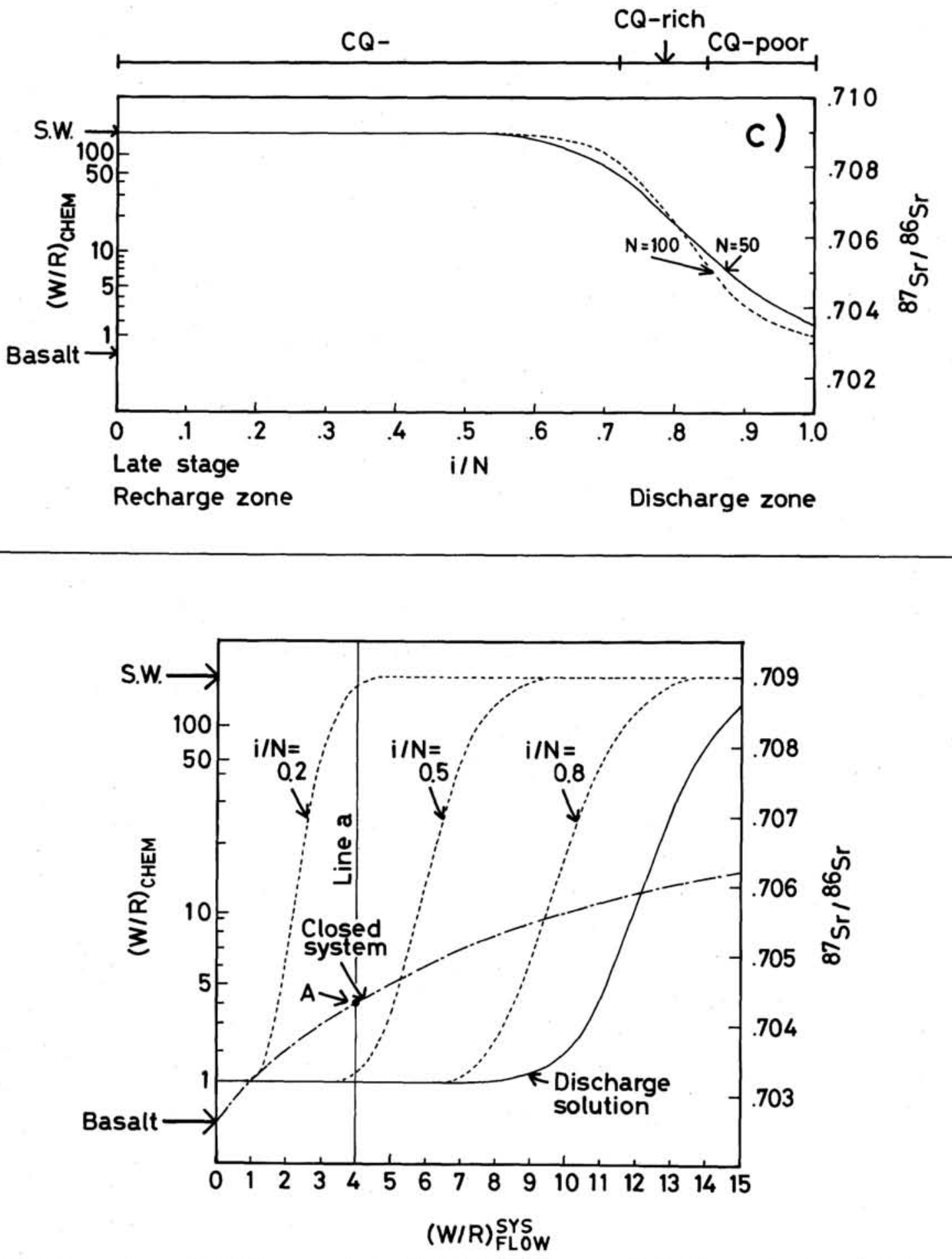

Fig. 4. Comparison of $[\mathrm{W} / \mathrm{R}]_{\mathrm{CHEM}}$ ratio $\left(\mathrm{or}{ }^{87} \mathrm{Sr} /{ }^{86} \mathrm{Sr}\right.$ ratio) versus $[\mathrm{W} / \mathrm{R}]_{\mathrm{FLOW}}^{\mathrm{SYS}}$ ratio plot of discharge hydrothermal solution between the flow (solid and broken lines) and closed systems (dash-dot line). Broken lines represent variation curves corresponding to recharge zone $(i / N=0.2)$, center of the system $(i / N=0.5)$, and discharge zone $(i / N=0.8)$. Line $a$ indicates that the two dintinct water/rock ratios $\left([W / R]_{F L O W}^{S Y S}[W / R]_{\text {CHEM }}\right)$ show an identical value of 4 only at point $A$. 
minimum value (1.0) of $[\mathrm{W} / \mathrm{R}]_{\mathrm{CHEM}}$. These results are consistent with that both greenstones and hot spring solutions from the hydrothermal systems along mid-ocean ridges indicate waterrock ratios higher than 1.0.

Application of the ideal flow model to submarine hydrothermal fields

1. The relation between mass flux from hydrothermal system and alteration of oceanic crust

The mass flux of strontium from hydrothermal solutions to the ocean is important. Strontium which is retained in or released from rocks during the hydrothermal alteration should correspond to the net hydrothermal flux to the ocean, which can be described by the following formula (4) and corresponds to the shaded region of Fig. 5 .

$$
\begin{aligned}
\text { FLUX }_{N E T}= & V \times L \times \int_{0}^{1}[R(n, t)-0.70265] \\
& \times C_{\text {ROCK }} d(i / N),
\end{aligned}
$$

where

$\mathrm{V}$ is the volume of each cell

$\mathrm{L}$ is the length of each cell and

$\mathrm{C}_{\mathrm{ROCK}}$ is the strontium concentration in rock.

Since the ${ }^{87} \mathrm{Sr} /{ }^{86} \mathrm{Sr}$ ratio of seawater is higher than that of discharge solution, some ${ }^{87} \mathrm{Sr}$ moves from the solution to rock, while some ${ }^{86} \mathrm{Sr}$ also moves from rock to the solution. The degree of ${ }^{87} \mathrm{Sr}$ enrichment varies depending upon types of greenstone, for example, ${ }^{87} \mathrm{Sr} /{ }^{86} \mathrm{Sr}$ ratio increases in the order of chlorite-quartz-(CQ-)poor $<\mathrm{CQ-}$ rich $<$ CQ-greenstones. In the intermediate evolution stage, CQ-poor rocks cover about $65 \%$ of the system, but gain a relatively small amount of ${ }^{87} \mathrm{Sr}$ from the solution. On the other hand, CQrich and CQ-greenstones occupy only about $35 \%$ of the system, but hold more than $65 \%$ of the net gained ${ }^{87} \mathrm{Sr}$ from the solution (Fig. 5). These results suggest that the CQ-rich and CQgreenstones, which are not directly in equilibrium with end-member hydrothermal solutions, play a very important role in the strontium budget of the hydrothermal system. This property could apply to the mass flux of other elements because it is linked with the parameter of water/rock ratio ([W/R $]_{\text {CHEM }}$ ).

2. Energy constraints of submarine hydrothermal systems

Seafloor hydrothermal fields at $21^{\circ} \mathrm{N}$ and $13^{\circ} \mathrm{N}$, East Pacific Rise, where many active vents

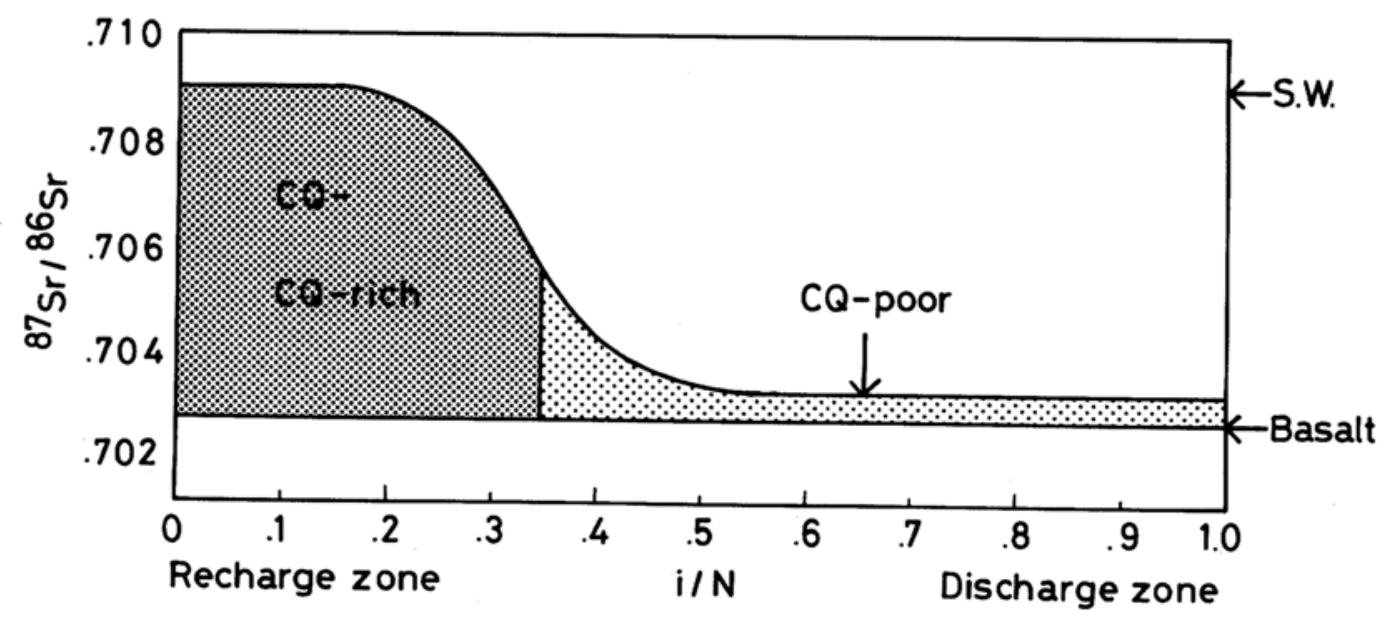

Fig. 5. Strontium isotope ratios of different types of altered rocks in rock column at the intermediate stage. Chlorite-quartz-(CQ-)rich and CQ-greenstones occupy about $35 \%$ of the system, but hold more than $65 \%$ of the ${ }^{87} \mathrm{Sr}$ gained from seawter. 


\section{EARLY STAGE $\longrightarrow$ INTERMEDIATE STAGE}

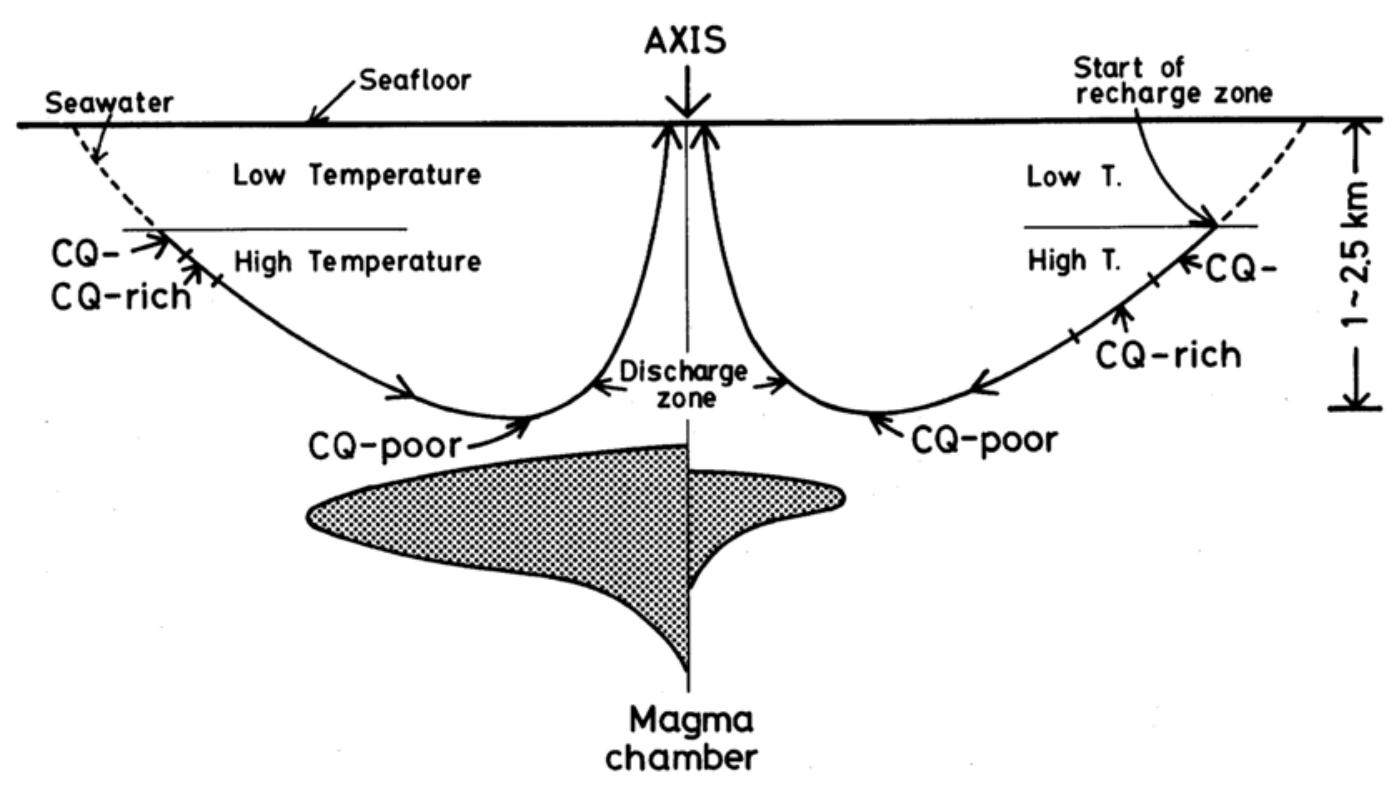

Fig. 6. Schematic model of the evolution of mid-ocean ridge hydrothermal system. (1) Early stage: chloritequartz-(CQ-)poor rocks occupy the majority of the system. CQ- and CQ-rich rocks appear near the recharge zone. (2) Intermediate stage: The area of CQ-poor rocks diminishes in the system. CQ-rick or CQ-rocks occupy a greater part of the system, but the chemistry of the discharge solution shows no change. The hydrothermal activity declines as magma, the main heat source, solidifies and cools down. (3) Late stage: this stage is not seen in natural axis hydrothermal systems because solidified magma had exhausted heat energy to drive hydrothermal convection system.

and relatively small amounts of fresh sulfide deposits are found, may belong to a fairly early evolutionary stage. On the other hand, Clambake I (one of the hydrothermal vent fields on the Galapagos Rift $86^{\circ} \mathrm{W}$ ), the outer portion of which is inactive, suggests that this vent, as well as others having major dead areas, may be already showing down and will die out (Crane and Ballard, 1980). Hydrothermal activity which formed the greenstones of DSDP Hole 504B died out about 6 million years ago (Kawahata and Furuta, 1985; Alt et al., 1985). These four hydrothermal fields probably represent evolutionary stages of hydrothermal systems and indicate water-rock interaction with low water/rock ratios. So rocks with low water/rock ratios (ca. 1.0) occupy the discharge zone as long as hydrothermal circulation is active.
The life time of the submarine hydrothermal systems is probably controlled by the heat source energy. If the heat emanated from a magma chamber drives hydrothermal circulation (Macdonald et al., 1980; Macdonald, 1982), then $1 \mathrm{~g}$ of basaltic magma cooling from $1200^{\circ} \mathrm{C}$ down to $350^{\circ} \mathrm{C}$ makes about $1 \mathrm{~g}$ of hydrothermal solution heated from 0 up to $350^{\circ} \mathrm{C}$ (Spooner and Fyfe, 1973). If gabbroic (ancient magma chamber) layer is $4 \mathrm{~km}$ thick (Rise Project Group, 1980) and seawater circulates mainly in the upper oceanic crust (about $2 \mathrm{~km}$ thick) (Spooner, 1979; Bischoff, 1980; Ito and Clayton, 1983), and if all magma is solidified near the spreading axis and heat is exchanged between magma and circulating water completely, the integrated volume water/rock ratio ([W/R $]_{\text {FLOw }}$ ) would be about 2.0. Although the assumption is made that all oceanic crust attains equilibrium with hot spring 
solutions along the main paths of circulation flow, another important factor must be considered. That is, there are usually relicts of plagioclase and/or clinopyroxene in greenstone, which indicates that some portions of rocks resist hydrothermal alteration (Humphris and Thompson, 1978; Kawahata and Furuta. 1985; Alt et al., 1985). For example, if only 50\% of rock in volume is altered to secondary minerals, the substantial integrated volume water/rock ratio (4.0) would be twice as large as that of the ideal condition. Greenstones recovered from $890 \mathrm{~m}$ to over $1350 \mathrm{~m}$ subbottom depth at the Galapagos Spreading Center contain on average $33 \%$ of unaltered minerals (Kawahata et al., 1987). Thus an integrated volume water/rock ratio ([W/R $]_{\text {FLow }}$ ) is estimated to be up to 3 . In fact, all magma could not cool down as low as $350^{\circ} \mathrm{C}$ nor heat exchange can be complete, so these values are probably an upper limit. These values suggest that a hydrothermal system will die out at the intermediate evolutionary stage.

The schematic model of a hydrothermal system is shown in Fig. 6. Hydrothermal circulation begins with a supply of heat energy from an underlying magma chamber. The discharging end-member hydrothermal solution with water/rock ratio of 1.0 meets cold seawater to form sulfide/oxide deposits on or within the oceanic crust. As time passes, chlorite-quartz(CQ-)rich rocks replace CQ-poor ones and occupy larger part of the hydrothermal system. But CQ-poor rocks still exist near the discharge zone, which control the constancy of the chemical composition of end-member hydrothermal solutions. When magma solidifies and cools down, the hydrothermal activity declines.

\section{Summary and Conclusions}

The significant characteristics of submarine hydrothermal systems associated with spreading axes are the similarities in water/rock ratios and the chemistry of end-member hydrothermal solutions, and greenstones, and the stability of these properties with time. The natural system has been simplified to an ideal flow model which in- corporates major rock types associated with submarine hydrothermal systems, water/rock ratios and strontium isotope ratios. The model predicts the following properties:

(1) Three evolutionary stages of hydrothermal alteration. Early stage: chlorite-quartz(CQ-)rich greenstones occur only in the recharge zone while CQ-poor rocks occur in the rest of the system. Intermediate stage: the increase of fluid flow through rock ([W/R $]_{\text {FLOw }}$ ) promotes replacement of CQ-poor with CQ-rich and CQrich with CQ-greenstones, respectively. Late stage: CQ-poor greenstones are completely replaced by CQ- and CQ-rich greenstones. All three stages are accompanied by progressive changes in ${ }^{87} \mathrm{Sr} /{ }^{86} \mathrm{Sr}$ ratios.

(2) The chemical composition of endmember hydrothermal solutions will remain constant until the system proceeds to the intermediate evolutionary stage.

(3) The water/rock ratio for a closed system deduced from chemistry ([W/R $]_{\text {CHEM }}$ ) is, in general, different from the integrated volume water/rock ratio ([W/R $\left.]_{\text {FLow }}\right)$.

(4) The quantity of elements or isotopes which are fixed in or released from rocks during hydrothermal alteration corresponds to the net hydrothermal flux to the ocean, except for deposition on or within the crust. CQ-rich and CQ-greenstones, which constitute a relatively small portion of the system and are not directly in equilibrium with end-member hydrothermal solutions, play an important role in mass flux calculation for the intermediate stage.

(5) The integrated volume water/rock ratio ([W/R $]_{\text {FLOW }}$ ) constrained by the energy of heat source is estimated to be up to 4 based upon theoretical calculations and observations in the drill core of Hole 504B. This suggests that hydrothermal activity dies out at about the intermediate evolution stage.

Acknowledgments-The author would like to express his appreciation to Prof. J. T. Iiyama for valuable discussions and instructive suggestions. He thanks Drs. N. Shikazono, N. Takeno, M. J. Mottl and T. F. McConachy for reading the manuscript and valuable criticism. He is much indebted to Drs. T. Urabe, $\mathrm{K}$. 
Fujimoto, and M. Nohara for valuable discussions and reading an early version of the manuscript and to Mr. I. Igarashi for figure photographs.

\section{REFERENCES}

Albarede, F., Michard, A., Minster, J.F. and Michard, G. (1981) ${ }^{87} \mathrm{Sr} /{ }^{86} \mathrm{Sr}$ ratios in hydrothermal waters and deposits from the East Pacific Rise at $21^{\circ}$ N. Earch Planet. Sci. Lett. 55, 229-236.

Alt, J. C., Leverne, C. and Muehlkenbachs, K. (1985) Alteration of the upper oceanic crust: mineralogy and processes in Deep Sea Drilling Prohect Hole 504B, Leg83. Initial Reports of Deep Sea Drilling Project 83, 217-247.

Anderson, R. N., Honnorez, J. and other scientific party (1982) DSDP Hole 504B, the first reference section over $1 \mathrm{~km}$ through Layer 2 of the oceanic crust. Nature 300, 589-592.

Becker, K., Langseth, M. G., Von Herzen, R. P. and Anderson, R. N. (1983) Deep crustal geothermal measurements, Hole 504B, Costa Rica Rift. J. Geophys. Res. 88, 3447-3457.

Bischoff, J. (1980) Geothermal system at $21^{\circ} \mathrm{N}$, East Pacific Rise: Physical limits on geothermal fluid and role of adiabatic expansion. Science 207, 14651469.

Bischoff, J. and Dickson, F. W. (1975) Seawaterbasalt interaction at $200^{\circ} \mathrm{C}$ and 500 bars: Implications for origin of sea-floor heavy-metal deposits and regulation of seawater chemistry. Earth Planet. Sci. Lett. 25, 385-397.

Bowers, T. S. and Taylor, H. P. (1985) An integrated chemical and stable-isotope model of the origin of mid-ocean ridge hot spring system. J. Geophys. Res. 90, 12583-12606.

Burk, W. H., Denision, R. E., Hetherington, E. A., Koepnick, R. B., Nelson, H. F. and Otto, J. B. (1982) Variation of seawater ${ }^{87} \mathrm{Sr} /{ }^{86} \mathrm{Sr}$ throughout Phanerozoic time. Geology 10, 516-519.

Coverse, D. R., Holland, H. D. and Edmond, J. M. (1984) Flow rates in the axial hot springs of the East Pacific Rise $\left(21^{\circ} \mathrm{N}\right)$ : implications for the heat budget and the formation of massive sulfide deposits. Earth Planet. Sci. Lett. 69, 159-175.

Corliss, J. B., Dymond, J., Gordon, L. I., Edmond, J. M., Von Herzen, R. P., Ballard, R. D., Green, K., Williams, D., Bainbridge, A., Crane, K. and Van Andel, T. H. (1979) Submarine thermal springs on the Galapagos Rift. Science 203, 1073-1083.

Crane, K. and Ballard, R. D. (1980) The Galapagos Rift at $86^{\circ} \mathrm{W}: 4$. structure and morphology of hydrothermal fields and their relationship to the volcanic and tectonic processes of the rift valley. $J$. Geophys. Res. 85, 1443-1454.
East Pacific Rise Study Group (1981) Crustal processes of the Mid-Ocean Ridge. Science 213, 31-40.

Edmond, J. M., Bowers, T. S. and Campbell, A. (1985) "Black smokers" at $21^{\circ} \mathrm{N}, \mathrm{EPR} ; 1979,1981$, 1985. EOS 66, 921.

Edmond, J. M., Measures, C., McDuff, R. E., Chan, L. H., Collier, J. B., Grant, B., Gordon, L. I. and Corliss, J. B. (1979) Ridge crest hydrothermal activity and the balances of major and minor elements in the ocean: The Galapagos data. Earth Planet. Sci. Lett. 46, 1-18.

Edmond, J. M., Von Damm,. K. L., McDuff, R. E. and Measures, C. I. (1982) Chemistry of hot springs on the East Pacific Rise and their effluent dispersal. Nature 297, 187-191.

Hajash, A. (1975) Hydrothermal processes along midocean ridges: An experimental investigation. Contrib. Mineral. Petrology 53, 205-226.

Hart, R. A. (1970) Chemical exchange between seawater and deep-ocean basalt. Earth Planet. Sci. Lett. 19, 269-279.

Hart, R. A. (1973) A model for chemical exchange in the basalt-seawater system of oceanic layer II. Can. J. Earth Sci. 10, 799-815.

Hart, S. R., Erlrank. A. J. and Kable, E. J. D. (1974) Sea-floor basalt alteration: some chemical and isotopic effects. Contrib. Mineral. Petrol. 44, 219230.

Hekinian, R., Fevier, M., Bischoff, J. L., Picot, P. and Shanks, W. C. (1980) Sulfide deposits from the East Pacific Rise near $21^{\circ} \mathrm{N}$. Science 207, 14331444.

Humphris, S. E. and Thompson, G. 81978) Hydrothermal alteration of oceanic basalts by seawater. Geocheim. Cosmochim. Acta 42, 107125 .

Ito, E. and Clayton, R. N. (1983) Submarine metamorphism of gabbros from th Mid-Cayman Rise: an oxygen isotope study. Geochim. Cosmochim. Acta 47, 535-546.

Kawahata, H. and Furuta, T. (1985) Subseafloor hydrothermal alteration in the Galapagos Spreading Center. Chem. Geol. 49, 259-274.

Kawahata, H., Kusakabe, M. and Kikuchi, Y. (1987) Strontium, oxygen, and hydrogen isotope geochemistry of hydrothermally altered and weathered rocks in DSDP Hole 504B, Costa Rica Rift. Earth Planet. Sci. Lett. 85, 343-355.

Lister, C. R. B. (1974) On the penetration of water into hot rock. Geophys. J. Astr. Soc. 39, 4665-509.

Lowell, R. P. (1975) Circulation in fractures, hot springs, and convective heat transport on mid-ocean ridge crests. Geophys. J. Ast. Soc. 40, 351-365.

Macdonald, K. C. (1982) Mid-ocean ridges: fine scale tectonic, volcanic and hydrothermal processes 
within the plate boundary zone. Ann. Rev. Earth Planet. 10, 155-190.

Macdonald, K. C., Becker, K., Spiess, F. N. and Ballard, R. D. (1980) Hydrothermal heat flux of the "black smoker" vents on the East Pacific Rise. Earth Planet. Sci. Lett. 48, 1-7.

McConachy, T. F., Ballard, R. D., Mottl, M. J., Von Herzen, R. P. (1986) Geological form and setting of a hydrothermal vent field at lat $10^{\circ} 56^{\prime} \mathrm{N}$, East Pacific Rise: A detailed study using Angus an Alvin. Geology 14, 295-298.

McDuff, R. E. and Edmond, J. M. (1982) On the fate of sulfate during hydrothermal circulation at midocean ridges. Earth Planet. Sci. Lett. 57, 117-132.

Michard, G., Albarede, F., Michard, A., Minster, J. F., Charlo, J. L. and Tan, N. (1984) Chemistry of solutions from the $13^{\circ} \mathrm{N}$ East Pacific Rise hydrothermal site. Earth Planet. Sci. Lett. 67, 297-307.

Mottl, M. J. (1983) Metabasalts, axial hot springs and the structure of hydrothermal systems at mid-ocean ridges. Geol. Soc. Amer. Bull. 94, 161-180.

Mottl, M. J. and Holland, H. D. 81978) Chemical exchange during hydrothermal alteration of basalt by seawater-I. Experimental results for major and minor components of seawater. Geochim. Cosmochim. Acta 42, 1103-1115.

Mottl, M. J. and Seyfried, W. E. (1980) Sub-seafloor hydrothermal systems: Rock- vs. seawaterdominated, Seafloor spreading centers: Hydrothermal systems, Hutchinson and Ross, Ind., Stroudsburg, Pennsylvanis, Dowden. Rona, P. A. and Lowell, R. P., eds. 424p.

Ribando, R. J., Torrance, K. E. and Turcoffo, D. L. (1976) Numerical models for hydrothermal circulation in the oceanic crust. J. Geophys. Res. 81, 3007-3012.

RISE project group (1980) East Pacific Rise: Hot spring and geophysical experiments. Sicnece 207, 1421-1433.

Seyfried, W. E. (1977) Seawater-basalt interaction from $25-300^{\circ} \mathrm{C}$ and 1,500 bars: Implications for the origins of submarine metal-bearing hydrothermal solutions and regulation of ocean chemistry [Ph. D. thesis]: Los Angels, California, University of Southern California, 242p.

Seyfried, W. E. and Bischoff, J. L. (1977) Hydrothermal transport of heavy metals by seawater: The role of seawater/basalt ratio. Earth Planet Sci. Lett. 34, 71-77.
Seyfried, W. E. and Bischoff, J. L. (1981) Experimental seawater-basalt interaction at $300^{\circ} \mathrm{C}$ and 500 bars: Chemical exchange, secondary mineral formation and implications for the transport of heavy metals. Geocheim. Cosmochim. Acta 45, 135-147.

Seyfried, W. E. and Mottl, M. J. (1982) Hydrothermal alteration of basalt by seawater under seawaterdominated conditions. Geocheim. Cosmochim. Acta 46, 985-1002.

Shanks, W. C., Bischoff, J. L. and Rosenbauer, R. J. (1981) Seawater sulfate reduction and sulfur isotope fractionation in basaltic systems: Interaction of seawater with fayalite and magnetite at $200-300^{\circ} \mathrm{C}$. Geocheim. Cosmochim. Acta 45, 1977-1995.

Shanks, W. C., Koski, R. A. and Woodruff, L. G. (1984) Mineralogy and stable isotope systematics of sulfide deposits from the Juan de Fuca Ridge. EOS 45, 976.

Shikazono, N. and Holland, H. D. (1983) The partitioning of strontium between anhydrite and aqueous solutions from $150^{\circ} \mathrm{C}$ to $250^{\circ} \mathrm{C}$. Econ . Geol. Mon. 5, 320-328.

Spooner, E. T. C., Chapman, H. J. and Smewing, J. D. (1977a) Strontium isotopic contamination and oxidation during ocean floor hydrothermal metamorphism of the ophiolitic rocks of the Troodos Massif, Cyprus. Geochim. Cosmochim. Acta 41, 873-890.

Spooner, E. T. C., Beckinsale, R. D., England, P. C. and Senior, A. (1977b) Hydration ${ }^{18} \mathrm{O}$ enrichment and oxidation during ocean floor hydrothermal metamorphism of ophiolitic metabasic rocks from E. Liguria, Italy. Geochim. Cosmochim. Acta 41, 857-871.

Spooner, E. T. C. and Fyfe, W. S. (1973) Subseafloor metamorphism, heat and mass transfer. Contrib. Mineral. and Petrol. 42, 287-304.

Veizer, J. and Compston, W. (1974) ${ }^{87} \mathrm{Sr} /{ }^{86} \mathrm{Sr}$ composition of sea water during the Phanerozoic. Geochim. Cosmochim. Acta 38, 1461-1484.

Von Damm, K. L., Edmond, J. M., Grant, B., Measures, C. I., Walden, B. and Weiss, R. F. (1985) Chemistry of submarine hydrothermal solutions at $21^{\circ} \mathrm{N}$, East Pacific Rise. Geochim. Cosmochim. Acta 49, 2197-2220.

Zierenberg, R. A., Shanks, W. C. and Bischoff, J. L. (1984) Massive sulfide deposits at $21^{\circ} \mathrm{N}$ site, East Pacific Rise. Earth Planet. Sci. Lett. 66, 91-100. 